\title{
Effect of ethanol extract of Telfairia occidentalis leaf on some biochemical parameters of 2,4-dinitrophenyl hydrazine induced oxidative stress in albino rats
}

\author{
Oyedele Elliot SEYIFUNMI* and Ayorinde AJAYI \\ Department of Science Laboratory Technology, Rufus Giwa Polytechnic Owo, Ondo State, Nigeria
}

\begin{abstract}
In this study, we attempt to verify the claim that the leaf-extract of Telfairia occidentalis can remedy oxidative damage condition as well as assess its phytochemical content. Fifteen male albino rats weighing $180 \mathrm{~g}$ to $240 \mathrm{~g}$ were randomly divided into three groups of five rats each. Group A was designated the control group while group B and C were both induced with $40 \mathrm{mg} / \mathrm{kg}$ body weight 2,4-dinitrophenyl hydrazine. Group C was subsequently treated with 200 $\mathrm{mg} / \mathrm{kg}$ body weight of ethanol extract of $T$. occidentalis leaf for 21 days. At the end of the treatment, the animals were sacrificed, and serum of the samples were subjected to relevant tests. Result shows that the plant leaf contained saponin, tannins, alkaloids, flavonoids and phenols whereas, terpenes, steroids and anthraquinones were not detected. The serum enzymes alanine aminotransferase (ALT) and alkaline phosphatase (ALP) were significantly elevated from $17.43 \mathrm{u} / \mathrm{L}$ and $28.40 \mathrm{u} / \mathrm{L}$ to $21.60 \mathrm{u} / \mathrm{L}$ and $34.27 \mathrm{u} / \mathrm{L}$ respectively. These were significantly lowered in the group $\mathrm{C}$ to $18.37 \mathrm{u} / \mathrm{L}$ and $29.23 \mathrm{u} / \mathrm{L}$ respectively for ALT and ALP. Also, a significant lowering of superoxide dismutase (SOD) activity was observed in the treated group $(54.33 \mathrm{u} / \mathrm{mg}$ ) from $79.40 \mathrm{u} / \mathrm{mg}$ recorded in the intoxicated group. Similarly, a significant decrease in malondialdehyde was observed in the treated group $(25.80 \mathrm{u} / \mathrm{mg}$ ) relative to the intoxicated group (35.87 $\mathrm{u} / \mathrm{mg})$. Moreover, catalase activity in the treated group $(7.43 \mathrm{u} / \mathrm{mg}$ ) was significantly lower compared with the intoxicated group. Our observation confirmed that ethanolic leaf extract of $T$. occidentalis reversed the oxidative damage condition in albino rats. The result confirms the ethnomedicinal use of the plant in the management of oxidative stress related diseases.
\end{abstract}

Keywords: ethnomedicine, phytochemicals, malondialdehyde, oxidative stress, antioxidant

\section{Introduction}

The plant kingdom comprises vast natural resources whose potential have not been adequately utilized. The search for alternative medicine has led to the acceptance of ethnomedicine which is more a form of cultural approach to healthcare delivery [1]. Ethnomedicine, a part of holistic medicine, provides cheap but somehow crude medical practice for the majority of rural folk especially in Nigeria. Also, the emergence of new and drug-resistant pathogens is directing attention to herbal alternatives. Moreover, the concrete result from the treatment of infertility and other difficult health challenges is calling for concerted scientific investigation to authenticate the validity of the ethnopharmaceutics [2, 3]. Many prophylactics have been developed from plants with high therapeutic potency [4].

Telfairia occidentalis (fluted pumpkin) is one of such plants with numerous medicinal and nutritional benefits. The leaf, seed, root and entire shoot of $T$. occidentalis have been subjected to scientific investigation purposely to harness the nutritional benefits of the plant as well as verify the health impact attributed to it in haematinic properties [5-7].

T. occidentalis is among the most popular vegetable crops being propagated in the West African rainforest zone for its green leafy vegetable and ellipsoidal fruit which is very nutritious [8]. Oluwole et al. [9] reported that $T$. occidentalis has anti-inflammatory properties, Odoemena and Essien [10] documented the antibacteria attributes of the plant while Kayode et al. [7] reported that $T$. occidentalis leaf-supplemented protein diet is more effective than only protein meal for recovery of rats suffering from protein energy malnutrition induced by oxidative damage. The various extract of the plant has also been claimed to exhibit anti-diabetic anticholesterolemic, anti-hyperglycemic and anti-anaemic properties [11-15].

Moreover, the consumption of the leaf of $T$. occidentalis was reported to elicit hypolipidemic effect and can help to reduce the risk of cardiovascular disease $[5,16]$. Therefore, the present study was designed to assess the phytochemical constituents and the effect of $T$. occidentalis leaf extract on induced oxidative stress in albino rats.

\section{Experimental}

\subsection{Materials}

All the reagents used in this study were of analytical grade and they were sourced from Sigma-Aldrich Inc (Missouri, USA). The reagents were used as purchased without further purification or alteration. 


\subsection{Preparation of leaf extract}

Fresh green vegetable of Telfairia occidentaliswere bought at Oja-Oba, Owo, Ondo state, Nigeria, and brought to the Environmental Biology Laboratory of Rufus Giwa Polytechnic, Owo, for authentication where a voucher specimen was deposited. The leaves were washed with distilled water and shade dried for three weeks. The dried leaves were milled into powder form using a mechanical grinder. $250 \mathrm{~g}$ of the leaf powder were dissolved in $500 \mathrm{ml}$ of ethanol for 72 hours with occasional mixing using sterile glass stirrer. The suspension was then filtered with Whatman No. 1 filter paper and the filtrate subjected to rotary evaporation at $50{ }^{\circ} \mathrm{C}$ to produce a sticky greenish substance which was later reconstituted to $200 \mathrm{mg} / \mathrm{ml}$ extract with normal saline.

\subsection{Laboratory animals}

The albino rats (Rattus norvegicus) weighing between 180 and $240 \mathrm{~g}$ used in this study were procured from the Biochemistry Department, University College Hospital, Ibadan. The rats were kept in wooden cages at the animal house of the Science Laboratory Technology Department, Rufus Giwa Polytechnic, Owo, Nigeria, with free access to pelletized feed and portable water to acclimatize.

\subsection{Qualitative phytochemical screening}

All the tests described below were carried out on the extracts using the methods of Trease and Evans [17] and Sofowora [18].

\subsection{Toxicological study}

After two weeks of acclimatization, the rats were randomly divided into three groups of 5 rats each. Group A was the control, groups B and C were induced with 40 $\mathrm{mg} / \mathrm{kg}$ body weight 2,4-dinitrophenyl hydrazine. Group $\mathrm{C}$ was on the second day ( $24 \mathrm{~h}$ after inducement) treated on daily basis with $200 \mathrm{mg} / \mathrm{kg}$ body weight extract of $T$. occidentalis leaf till the $21^{\text {st }}$ day of the experiment. All the rats were fasted overnight to the $22^{\text {nd }}$ day and thereafter sacrificed through chloroform anesthesia and the blood collected through cardiac puncture. The blood was allowed to clot, and serum collected by centrifugation of the blood samples at $10,000 \mathrm{rpm}$ for 10 min. The serum was kept in the refrigerator.

Determination of the liver enzymes. Alanine aminotransferase (ALT), aspartate aminotransferase (AST) and alkaline phosphatase (ALP) were measured using Randox kits manufactured by Randox Laboratories, UK. The procedures were carried out as prescribed in the kits manual.

Determination of serum concentration of superoxide dismutase (SOD). The determination of superoxide dismutase was done using the procedure of [19] by assessing the inhibition of adrenaline at $\mathrm{pH} 10.2$ at 30 ${ }^{\circ} \mathrm{C}$.

Determination of malondialdehyde (MDA) level. Thiobabituric acid (TBARS) assay was done to measure the level of MDA according to the procedure of Rice Evan et al. [20].

Determination of catalase activity (CAT). Catalase activity in the serum was determined by the method described by Sinha [21] using standard Randox kit manufactured by Randox Laboratories, UK. The procedures were carried out as prescribed in the kit's manual.

\subsection{Statistical analysis}

Data were presented as mean \pm standard error (SE). Significant difference between different groups was tested using one-way analysis of variance (ANOVA) and treatment means were compared with Duncan's New Multiple Range Test using SSPS window 7 version 21.0 software. At $p<0.05$, the differences were considered significant.

\section{Results and discussion}

Medicinal plants have been described as those plants that produce active substances that may be used as cure of diseases or which can be used as precursor of new drugs [22]. The major bioactive substances produced by plants are the secondary metabolites which are generally referred to as phytochemicals.

The qualitative phytochemical screening of the leaf of the $T$. occidentalis leaf extract revealed the presence of saponin, tannins, alkaloids, flavonoids and phenols whereas terpenes, steroids and anthraquinones were not detected in the plant material.

The array of phytochemicals present in the leaf extract of $T$. occidetalis in this study, such as saponin, tannins, alkaloids, flavonoids, and phenols, have been reported earlier in different extracts of the plant leaf [14, $15,23]$. The presence of these phytochemicals may explain why the leaf is highly regarded among traditional healers in Nigeria as a potent remedy against many ailments.

Table 1. Qualitative phytochemical screening of $T$. occidentalis leaf extract

\begin{tabular}{lc}
\hline \multicolumn{1}{c}{ Phytochemical } & Present/Absent \\
\hline Saponin & + \\
Tannin & + \\
Terpenes & - \\
Anthraquinone & - \\
Steroids & - \\
Flavonoids & + \\
Alkaloids & + \\
Phenols & + \\
\hline
\end{tabular}

Key: + = detected, - = not detected

On intoxication, the serum enzymes ALT and ALP were significantly elevated from $17.43 \mathrm{u} / \mathrm{L}$ and $28.40 \mathrm{u} / \mathrm{L}$ to $21.60 \mathrm{u} / \mathrm{L}$ and $34.27 \mathrm{u} / \mathrm{L}$ respectively. These were significantly lowered in the group treated with $T$. occidentalis leaf extract to $18.37 \mathrm{u} / \mathrm{L}$ and $29.23 \mathrm{u} / \mathrm{L}$ respectively for ALT and ALP. There was no significant difference in the AST level of all the groups (Table 1).

The values of these various serum biomarkers fall within the normal range in the control group when compared with range of values contained in the "Lewis and Dacie practical hematology" [24]. The induction of the rats resulted to the elevation of the levels of ALT and ALP significantly. This observation agrees with that of Toma et al. [25].

According to Ramaiah [26] the ALP, AST and ALT serum enzymes are markers of health indices and are of importance as diagnostic tools clinical evaluation of the state of health of individuals. The liver and heart usually 
produce ALT and AST when under severe stress such as oxidative stress and increase in their concentrations in serum are indicators of liver and heart damage. Therefore, the lowering of the ALP and ALT significantly in rats treated with the ethanol extract of the $T$. occidentalis leaf is a good pointer to its potential in the management of oxidative stress related diseases.

Table 2. Effect of T. occidetalis leaf extract on serum enzymes in albino rats

\begin{tabular}{lccc}
\hline $\begin{array}{c}\text { Parameters } \\
\text { group }\end{array}$ & ALT $(\boldsymbol{\mu} / \mathbf{L})$ & AST $(\boldsymbol{\mu} / \mathbf{L})$ & ALP $(\boldsymbol{\mu} / \mathbf{L})$ \\
\hline (A) Control & $17.43 \pm 0.03^{\mathrm{a}}$ & $18.20 \pm 0.06^{\mathrm{a}}$ & $28.40 \pm 0.06^{\mathrm{a}}$ \\
(B) Intoxicated & $21.60 \pm 0.06^{\mathrm{b}}$ & $19.00 \pm 0.12^{\mathrm{a}}$ & $34.27 \pm 0.35^{\mathrm{b}}$ \\
(C) Treated & $18.37 \pm 0.07^{\mathrm{a}}$ & $18.53 \pm 0.03^{\mathrm{a}}$ & $29.23 \pm 0.09^{\mathrm{a}}$ \\
\hline
\end{tabular}

Note. Values are mean \pm SEM, values with different alphabet along column are significantly different at $p<0.05$.

Also, a significant lowering of superoxide dismutase activity towards the level of the control group $(36.67$ $\mathrm{u} / \mathrm{mg}$ ) was observed in the treated group $(54.33 \mathrm{u} / \mathrm{mg})$ from $79.40 \mathrm{u} / \mathrm{mg}$ recorded in the intoxicated group. Similarly, a significant decrease in MDA was observed in the treated group $(25.80 \mathrm{u} / \mathrm{mg})$ relative to the intoxicated group $(35.87 \mathrm{u} / \mathrm{mg})$. Moreover, catalase activity in the treated group $(7.43 \mathrm{u} / \mathrm{mg})$ was significantly lowered down to a level close to the control group $(7.20 \mathrm{u} / \mathrm{mg})$ compared with the intoxicated group $(8.10 \mathrm{u} / \mathrm{mg})$.

Similar pattern of significant increase and reduction were observed in the value of SOD and MDA in the intoxicated and treated groups. These values imply that the toxicant must have propagated free radicals leading to lipid peroxidation in the animals. These results corroborate the view of Talwar and Srivastava [27] with respect to serum enzymes under oxidative damage conditions. The lowering of the SOD and the MDA indicates a decreased production of oxygen free radicals by the $T$. occidentalis leaf extract.

Table 3. Effect of T. occidetalis leaf extract on serum antioxidants in albino rats

\begin{tabular}{llll}
\hline $\begin{array}{c}\text { Parameters } \\
\text { group }\end{array}$ & SOD $(\boldsymbol{\mu} / \mathbf{m g})$ & CAT $(\boldsymbol{\mu} / \mathbf{m g})$ & MDA $(\boldsymbol{\mu} / \mathbf{m g})$ \\
\hline (A) Control & $36.67 \pm 0.44^{\mathrm{c}}$ & $7.20 \pm 0.12^{\mathrm{b}}$ & $23.23 \pm 0.09^{\mathrm{b}}$ \\
(B) Intoxicated & $79.40 \pm 0.31^{\mathrm{a}}$ & $8.10 \pm 0.06^{\mathrm{a}}$ & $35.87 \pm 0.18^{\mathrm{a}}$ \\
(C) Treated & $54.33 \pm 0.88^{\mathrm{b}}$ & $7.43 \pm 0.07^{\mathrm{b}}$ & $25.80 \pm 0.40^{\mathrm{b}}$ \\
\hline
\end{tabular}

Note. Values are mean \pm SEM, values with different alphabet along column are significantly different at $p<0.05$.

SOD helps to remove superoxide anion radicals by turning them to hydrogen peroxide and oxygen. The increase in the serum SOD enzyme in the intoxicated group may be as a result of oxidative activation of enzyme protein or increased of their synthesis. Hence, the reduction of both SOD and MDA in the group treated with the $T$. occidentalis leaf extracts is indicative of a reduction in the accumulation of superoxide anion radicals with oxidative stress, which leads to the reduction in liver damage [28].

These reduction in the serum enzymes might be linked with the phytochemicals inherent in the $T$. occidentalis leaf which may be responsible for the antioxidant activities of the plant. Tannins are reported to be effective in the management of tissue inflammation in cancer prevention. Therefore, its presence in the leaf extract of the plant suggests that the plant may be a good source of active principles in the prevention and management of cancer [22].

Flavonoids have been reported to be efficient antioxidants and free radical scavengers, which help to prevent oxidative cell damage [29]. They have been identified to exert high level of antioxidant activity in man and their effects on human nutrition and health is considerable [30].

The presence of these phenolic compounds in the $T$. occidentalis leaf extract promotes their antioxidative activities which may have informed its use in African folklore medicine. Phenols are known to function as free radical chain reaction inhibitors which invariably confer the antioxidative potential on the plant material [31]. Phenols have also been reported as a having potential of combating oxidative stress syndrome.

\section{Conclusions}

The result and observation show that ethanol extract of Telfairia occidentalis is able to heal oxidative damage in animals exposed to such damage as shown in the lowering of various oxidative stress biomarker enzymes in this study. This activity may have been brought about as a result of the presence of phytochemicals such as saponin, tannins, alkaloids, flavonoids and phenols in the plant's leaf extract.

\section{Conflict of interest}

The authors declare no conflict of interest regarding the publication of this article.

\section{References}

[1]. L. Williams, Ethnomedicine, West Indians Medical Journal 4 (2006) 215.

[2]. V. Geware, S.K. Parjance, A.N. Erekar, S.K. Pattan, N.S. Dighe, B.S. Kuchekar, R.K. Godge, Female infertility and its treatment by alternative medicine: A review, Journal of Chemical and Pharmaceutical Research 1 (2009) 148-162.

[3]. D. Ashokkumar, U.K. Mazumder, M. Gupta, G.P. Senthilkumar, V.T. Selvan, Evaluation of antioxidant and free radical scavenging Activities of Oxystelma esculentum in various in vitro Models, Journal of Complementary and Integrated Medicine 1 (2008) 9.

[4]. G.A. Ayoola, H.A.B. Coker, S.A. Adesegun, A.A. Adepoju-Bello, K. Obaweya, E.C. Ezennia, T.O. Atangbayila, Phytochemical screening and antioxidant activities of some selected medicinal plants used for malarial therapy in South-Western Nigeria, Tropical Journal of Pharmaceutical Research 7 (2008) 1019-1024.

[5]. O.A. Adaramoye, J. Achem, O.O. Akintayo, M.A. Fafunso, Hypolipidaemic effect of Telfairia occidentalis [fluted pumpkin] in rats fed a cholesterol-rich diet, Journal of Medicine and Food 10 (2007) 330-316.

[6]. W.B. Vidona, A. Wadioni, Assessment of liver histomorphology and curative effect of chloroform extract of Telfairia occidentalis seed on carbon 
tetrachloride $\left(\mathrm{CCl}_{4}\right)$ induced liver toxicity in Wistar rats, Journal of Biomedical Sciences 4 (2018) 1-6.

[7]. G. Oboh, E.E. Nwanna, C.A. Elusiyan, Antioxidant and antimicrobial properties of Telfairia occidentalis (fluted pumpkin) leaf extracts, Journal of Pharmacology and Toxicology 2 (2006) 167-175.

[8]. B. Lawal, O.K. Shittu, A.A. Rotimi, I.A. Olalekan, A.A. Kamooru, P.C. Ossai, Effect of Methaol extract of Telfairia occidentalis on haematological parameters in Wistar rats, Journal of Medical Sciences 5 (2015) 246-250.

[9]. E.S. Oluwole, A.O. Falode, O.O. Ogundipe, Antiinflammatory effect of some common Nigerian vegetables, Nigerian Journal of Physiological Science 18 (2003) 35-38.

[10]. T.M. Salman, I.A. Alagbonsi, A.A. Feyitimi, P.O Ajayi, Telfairia occidentalis Hook.f. - associated haematopoietic effect is mediated by cytokines but independent of testosterone: A preliminary report, Journal of Ethnopharmacology 216 (2018) 157161.

[11]. A.O. Eseyin, A.C. Igbiasoiyi, E. Oforah, P. Ching, B.C. Okoli, Effects of leaf extract of Telfairia occidentalis on some biochemical parameters in rats, Global Journal of Pure and Applied Sciences 11 (2005) 17-19.

[12]. O.A. Eseyin, E. Oforah, B.D. Dooka, Preliminary study of the hypoglycemic action of the extract of the leaf of Telfairia occidentalis in normoglycemic Guinea pigs, Global Journal of Pure and Applied Science 6 (2000) 639-641.

[13]. O.A. Eseyin, E.J. Edoho, N.E. Godwin, A.C. Igboasoiyi, A. Ekpo, Effects of the leaf extract of Telfairia occidentalis on the pharmacokinetics of chloroquine in rats, International Journal of Biology and Chemistry 4 (2007) 256-260.

[14]. N.A. Ojo, E.O. Adewaren, M.B. Tijjani, M. Chiroma, J. Simon, B. Afisu, O.M. Mogbojuri, A.M. Wakil, Acute toxicity and effect of ethanolic extract of Telfairia occidentalis leaves of blood glucose level in normal rats, Voin Journal of Veterinary Science 9 (2012) 25-31.

[15]. H.C. Thompson, W.C. Kelly, Vegetable Crops, 5th Ed., pp. 120-125, Mac Graw Hill Publishing Company Ltd, New Delhi (1990).

[16]. C.E. Ugwu, J.E. Olajie, E.O. Alumana, A. Eeanyika, Comparative effects of the leaves of Verninia amygdalina and Telfairia occidentalis incorporated diets on the lipid profile of rats, Africa Journal of Biochemistry Research 5 (2011) 28-32.

[17]. G. Trease, W.A. Evans, Textbook of pharmacognosy, 13th Ed., pp. 19-21, Bailliere Tindall Ltd., London (1989).

[18]. A. Sofowora, Medicinal plants and traditional medicine in Africa, 2nd edition, pp. 134 - 156, Spectrum Books Limited, Ibadan, Nigeria (1993).

[19]. B. Melekh, I. Ilkiv, A. Lozynskyi, A. Sklyarov, Antioxidant enzyme activity and lipid peroxidation in rat liver exposed to celecoxib and lansoprazole under epinephrine-induced stress, Journal of Applied Pharmaceutical Science 10 (2017) 094099.

[20]. C. Rice-Evans, C.S. Omorphos, E. Baysal, Sickle cell membrane and oxidative damage, Biochemistry Journal 237 (1986) 265-269.

[21]. A.K. Sinha, Enzymic synthesis of saccharopine14C, Annals of Biochemistry 43 (1971) 468-471.

[22]. B.O. Opawale, A.M. Oyetayo, A.R. Agbaje, Phytochemical screening, antifungal and cytotoxic activities of Trichilia heudelotii Planc (Harm), International Journal of Sciences: Basic and Applied Research 24 (2015) 267-276.

[23]. A.A.A. Kayode, O.T. Kayode, Some Medicinal Values of Telfairia occidentalis: A review, American Journal of Biochemistry and Molecular Biology 1 (2011) 30-38.

[24]. B. Bain, I. Bates, M. Laffan, S. Lewis, Lewis and Dacie practical haematology, 11th edition, Churchil Livingstone, pp. 304-320 (2011).

[25]. I. Toma, N.C. Victory, Y. Kabir, The effect of aqueous leaf extract of fluted pumpkin on some hematological parameters and liver enzymes in 2,4-dinitrophenylhydrazine induced anaemic rats, African Journal of Biochemistry Research 9 (2015) 95-98.

[26]. S. K. Ramaiah, Preclinical safety assessment: current gaps, challenges and approaches in identifying translatable biomarkers of drug induced liver, Clinical Laboratory Medicine 31 (2011) 161-72.

[27]. G.P. Talwar, L.M. Srivastava. Textbook of Biochemistry and Human Biology 3rd Ed., PHI Learning Ltd, pp. 266-267 (2012).

[28]. O.O. Daramola, W.A. Oyeyemi, L.O Odiase, A.A. Olorunfemi, Effects of methanol extract of Telfairia occidentalis seed on ovary antioxidant enzymes, serum hormone concentration and histology in Wistar rats, International Journal of Pharmacognosy and Phytochemical Research 8 (2016) 1245-1249.

[29]. D. Okwu, Phytochemicals, vitamins and mineral contents of two Nigeria medicinal plants, International Journal of Molecular Medicine and Advance Sciences 1 (2005) 375-381.

[30]. J. Omale, P.N. Okafor, Comparative antioxidant capacity, membrane stabilization, polyphenol composition and cytotoxicity of the leaf and stem of Cissus multistriata, African Journal of Biotechnology 17 (2008) 3129-3133.

[31]. F. Shahidi, P.K.J.P.D. Wanasundara, Phenolic antioxidants: Critical Reviews. In: Food Science and Nutrition 32 (1992) 67-103.

Received: 20.08 .2020

Received in revised form: 23.09.2020

Accepted: 25.09.2020 